\title{
The Cultivation of Applied Undergraduate Talents against the Backdrop of "Made in China 2025"
}

\author{
Yihua $\mathrm{Li}^{\mathrm{a}}$, Anhang Zhu ${ }^{\mathrm{b}}$, Xin Zhang, Feifei Fan, Jian Yuan \\ School of Mechanical Engineering, Anhui University of Science and Technology \\ Huainan Anhui, 232001, China \\ a'Lyh511@126.com, b1369251146@qq.com
}

\begin{abstract}
Made in China 2025"strategic plan has proposed several principles such as innovation-driven, intelligent transformation, strengthening base and green development and so on. It is an inevitable choice to promote our country from a big manufacturing towards a manufacturing power. Colleges and universities are important strength of the implementation of "Made in China 2025", they must establish an innovative educational concept, cultivate new application-oriented undergraduates. This article mainly analyzed the role of applied undergraduate talents in manufacturing as well as the current situation and the problems which are existing, furthermore mainly studied the opportunities and challenges the applicationoriented undergraduates faced against the backdrop of "Made in China 2025". On this basis, this paper established the training program for the application-oriented undergraduates against the backdrop of Made in China 2025".
\end{abstract}

Keywords - "Made in China 2025"; Applied talents; culture; Undergraduate education

\section{INTRODUCTION}

On May 19, 2015, the state council issued "Made in China 2025", the core of which is to accelerate the innovation and development of manufacturing industry and improve the quality and efficiency of manufacturing, and to transform from a manufacturing country to a manufacturing power [1]. Manufacturing industry is the main body of the national economy. In any era, the development of economy cannot be maintained without manufacturing. The implementation of the "Made in China 2025", is dependent on the applied talents' with high skill, undergraduate education application as a highly skilled personnel training base, how to quickly effective docking "Made in China 2025", service development, made in China play a better ability to undergraduate education service the economic and social, improve the modern undergraduate education system and improve the high-skilled personnel training mode, is still our focus of concern. "Made in China $2025^{\prime \prime}$ is to build an internationally competitive manufacturing industry in China, making our country one of the world's manufacturing powers. The biggest problem is the shortage of applied talents. It is urgent to cultivate a practical talent that can make "made in China 2025".

\section{THE Role Of APPLIED UndERGRAduATE TALENTS IN MANUFACTURING}

Manufacturing is the manufacturing resources (extraction of natural material resources, agricultural or industrial raw materials, etc.) of semi-finished products processing and reprocessing, provides the means of production for the production department, provide consumer goods production department for the society. As the main way of human society to create material wealth and the pillar industry of national economy, manufacturing industry is the dominant force in the industrialization and modernization, to ensure the material is the national security and people's happiness, is a measure of a country or a region an important symbol of comprehensive economic strength and international competitiveness.

Applied undergraduate talents is the subject of applied talents. Under the background of "Made in China 2025", due to the emergence of intelligent factory, end-to-end digital network can better service to create intelligent products, procedures and process, able to manage complex things, and more efficient manufacturing products [2]. Under the driving of this model, the cultivation of applied undergraduate talents is the need of economic and social transformation and upgrading, and it is also the necessity of the higher institutions to make clear their orientation and seek rational development. Personnel training mode of applied undergraduate colleges, we must break the bondage of traditional personnel training mode, change the education target fuzzy, students employment for the status quo of unclear, problem solving ability is weak, efforts to develop strong social adaptation ability, especially the career adaptation and development ability, meet the needs of the development of advanced manufacturing technology of applied undergraduate talents.

\section{CuRrent Situation And Main Problems OF APPLIED UNDERGRADUATE TALENTS}

With the rapid development of China's economic science and technology, there is an urgent need for high-level technical application talents. Education has realized the transformation from "elite education" to "popularization education". In this context, the concept of applied undergraduate education has been put into practice quickly. As can be seen from the basic structure of national education system, are shown in figure 1 below, applied talents is the inevitable trend in the 
development of higher education, applied talents training is the objective requirement of the social and economic development. Since 2001, some colleges and universities have proposed that schools should be positioned to cultivate high-level application-oriented talents adapting to the needs of society, and the "education collaboration group for undergraduate application" is established [3]. The country's economic development needs a large number of applied talents, with the deepening of China's industrialization process, the rapid economic development of local economy and industry, and a large increase in demand for applied talents, the social and economic development is an urgent need to cultivate the quality of institutions of higher learning, ability, knowledge and so on many aspects are different levels of applied talents to satisfy the needs of the work [4].

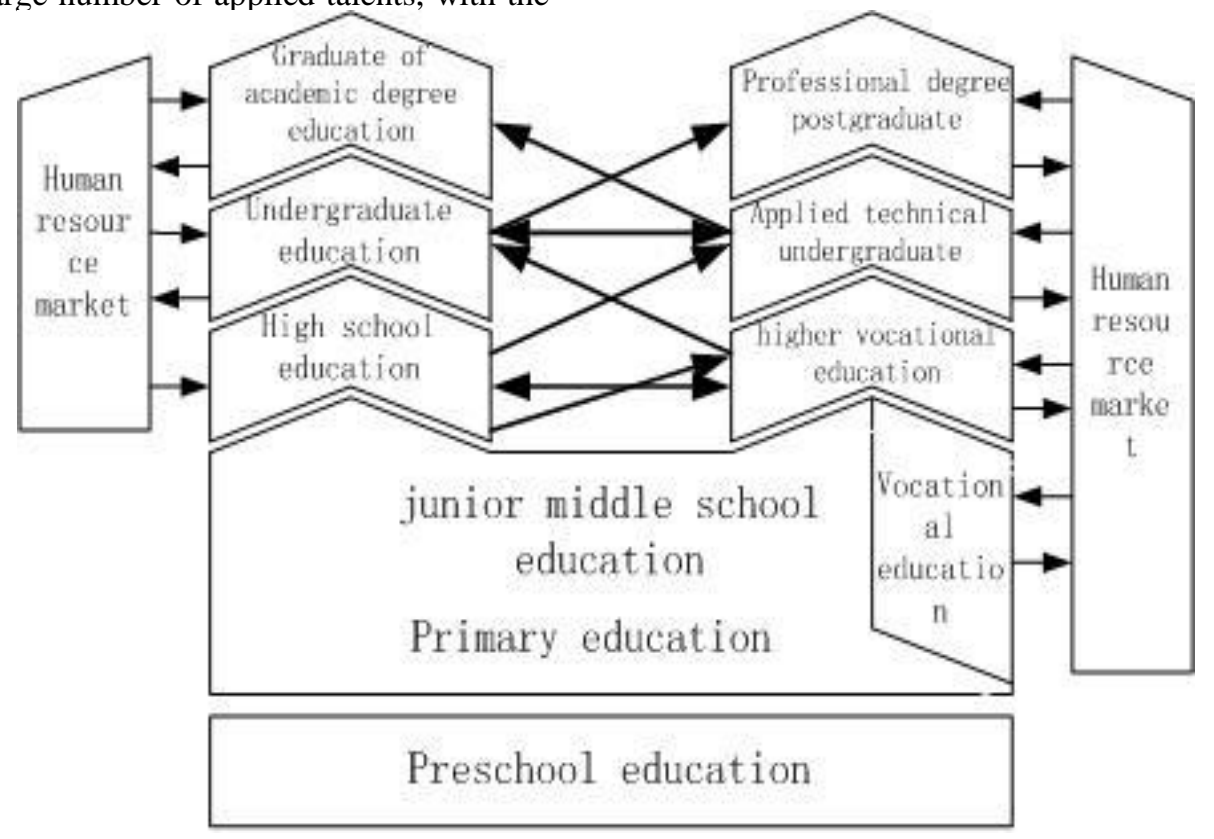

Fig. 1. Schematic diagram of the basic framework of the national education system

\section{New Requirements And New Challenges For The Culutivation Of ApPlied UndergRaduate Talents By MADE IN CHINA 2025}

"Made in China 2025" is a major trend that conforms to the current round of technological revolution and industrial transformation. In recent years, countries around the world, especially developed countries, have launched a strategy of manufacturing development. As shown in table 1, "Made in China 2025" is aimed at intelligent manufacturing as the main direction of attack, and the all-round intelligent transformation is carried out to make China's manufacturing industry stronger and stronger [5].

Under the background of "Made in China 2025", applied undergraduate talents is facing new opportunities and challenges, intelligent manufacture of the fourth industrial revolution, described by the centralized control to the basic model of distributed enhanced control, goal is to create a personalized and highly flexible production mode of digital products and services .It aims to transform the manufacturing industry into an intelligent transformation through the use of information communication technology and the virtual system of network space - information physical system (CPS). In this process, the new requirements for applied undergraduate culture are put forward. Intelligent is made of 2025 China's future development direction, as in the process of intelligent manufacturing execution carrier, automatic detection equipment, automatic assembly equipment, industrial intelligent robots, unmanned aerial vehicle (uav), data acquisition and storage equipment and so on independent research and development and design is an indispensable important segment. Through the large-scale application of such equipment, the traditional manufacturing industry will be transformed into "smart factory". The development of artificial intelligence technology provides an effective method for the analysis and processing of data and information in the production process, which adds intelligent wings to manufacturing technology. Artificial intelligence technology is especially suitable for solving complex and uncertain problems. The application of this technology in manufacturing will definitely improve the intellectualization of manufacturing industry. Driven by the integration of Internet and industrialization, the future manufacturing industry will be a frontier field of comprehensive application of various disciplines. The traditional segmentation of talent professional structure has not adapted to the development needs. Therefore, it is the direction of the future information industry talent demand that multi-specialized compound talents will be the future information industry talents. The importance of system design, debugging, maintenance and other talents will become increasingly prominent [6]. 
TABLE I. THE REINDUSTRIALIZATION STRATEGY ISSUED BY SOME DEVELOPED COUNTRIES IN RECENT YEARS

\begin{tabular}{|c|c|c|c|}
\hline Publish time & Strategic name & Main content & Strategic objectives \\
\hline In2012 & $\begin{array}{l}\text { The national strategic plan for } \\
\text { advanced manufacturing in } \\
\text { the United States }\end{array}$ & $\begin{array}{l}\text { The five goals and specific proposals for } \\
\text { eg, labor, partnership, federal investment } \\
\text { and research and development investment } \\
\text { are put forward }\end{array}$ & $\begin{array}{l}\text { To promote the development } \\
\text { of advanced American } \\
\text { manufacturing industry }\end{array}$ \\
\hline In2013 & $\begin{array}{l}\text { U.S. manufacturing } \\
\text { innovation network program }\end{array}$ & $\begin{array}{l}\text { The plan is to build a national innovation } \\
\text { network of } 45 \text { manufacturing innovation } \\
\text { centers and a coordinated network to focus } \\
\text { on key manufacturing technologies with } \\
\text { potentially revolutionary impacts such as } \\
\text { 3D printing }\end{array}$ & $\begin{array}{l}\text { We will continue to focus on } \\
\text { manufacturing technology } \\
\text { innovation and transform the } \\
\text { technology into a market-oriented } \\
\text { manufacturing base }\end{array}$ \\
\hline In2013 & German industry 4.0 strategy & $\begin{array}{l}\text { Building a network: information physical } \\
\text { system network; Research topic: intelligent } \\
\text { factory and intelligent production; } \\
\text { Implementation of three integrations: } \\
\text { horizontal integration, vertical integration } \\
\text { and end-to-end integration; Implement } \\
\text { eight security plans }\end{array}$ & $\begin{array}{l}\text { Change the current industrial } \\
\text { production and service mode } \\
\text { through the integration of } \\
\text { information network and physical } \\
\text { production system; Make } \\
\text { Germany the creator of advanced } \\
\text { intelligent manufacturing } \\
\text { technology }\end{array}$ \\
\hline In2014 & $\begin{array}{l}\text { White paper on } \\
\text { manufacturing in Japan }\end{array}$ & $\begin{array}{l}\text { Focus on developing robots, next } \\
\text { generation clean energy vehicles, } \\
\text { regenerative medicine and 3D printing }\end{array}$ & $\begin{array}{l}\text { Revitalize the domestic } \\
\text { manufacturing sector and revive } \\
\text { the Japanese economy }\end{array}$ \\
\hline In2015 & British manufacturing 2025 & $\begin{array}{l}\text { Advancing services+ in manufacturing } \\
\text { (production-centric value chains); We are } \\
\text { committed to faster and more responsive } \\
\text { consumer demand, grasping new market } \\
\text { opportunities, sustainable development, } \\
\text { and increasing efforts to cultivate high- } \\
\text { quality workforce }\end{array}$ & $\begin{array}{l}\text { Revitalize British manufacturing } \\
\text { and enhance international } \\
\text { competitiveness }\end{array}$ \\
\hline In2013 & $\begin{array}{l}\text { The French "new industries" } \\
\text { strategy }\end{array}$ & $\begin{array}{l}\text { To solve the three major problems of } \\
\text { energy, digital revolution and economic } \\
\text { life, we identified } 34 \text { priority industrial } \\
\text { projects, such as the new generation of } \\
\text { high-speed trains, electric planes, energy- } \\
\text { efficient buildings and intelligent textiles }\end{array}$ & $\begin{array}{l}\text { By innovating and reshaping } \\
\text { industrial strength, France is in the } \\
\text { first echelon of industrial } \\
\text { competitiveness }\end{array}$ \\
\hline
\end{tabular}

\section{TO MAKE APPLICATION ORIENTED UNDERGRADUATE} TALENTS TRAINING PROGRAM IN "MADE IN CHINA 2025"

Under the background of "Made in China 2025" applied undergraduate talents training should follow the basic law of undergraduate education, in colleges and universities and the academy by the carrier, we will deepen reform of the education, science and technology system, according to the industry standard of professional standards talents, fully tap the human and technical resources, explore the new applied talents training system and experience.

First, push the thinking mode of intelligent manufacturing shift, set up "Market oriented, enterprise participation" program, increase the intelligent manufacturing professional education related courses, creating more multidisciplinary institute to build intelligent manufacturing professional model, with the Internet of things, real-time positioning, physical information integration, network security and so on curriculum construction as the guide, relying on the mechanical design and manufacturing and its automation, electrical engineering and its automation, automation, computer science and technology, electronic information engineering and other professional technical force to build intelligent manufacturing.
Second, create industry-university-institute cooperation mode, the establishment of advanced manufacturing engineering training base, service for excellent engineering applied talents training, optimize the resources construction of engineering training teaching system, to better promote the development of engineering education mode. At the same time, we should pay attention to education, create the education base of engineering culture quality, expand the education system of resource construction engineering, and cultivate the interdisciplinary talent service. The quality of personnel training is based on market inspection, and the index of employment and employment quality is the main criterion. Application-oriented undergraduate talents are located in the industry, employing units are the most vocal evaluation subjects, and the market is the examination room of the quality of the training of applied undergraduate talents.

Finally, "Internal external guide" to strengthen the construction of teachers' engineering practice ability, for now, now of the applied undergraduate colleges and universities teachers are not enough to cope with the current engineering practice, the school should strengthen the construction of double, through internal training, will not have the requirements of the applied talents training teachers to enterprise (or institution) exercise training, improve their engineering practice ability . "External citation" refers to the 
process of introducing the theoretical, practical dual-level teachers with application-oriented talent teaching qualifications, or inviting the engineers of enterprises to participate in the training of applied talents.

\section{CONCLUSION}

It is necessary for the transformation and upgrading of economic and social transformation, and it is necessary for institutions of higher learning to seek rational development. The personnel training mode of applied undergraduate colleges, must be based on the current economic development needs, give full play to the reform of faculty to the subjective initiative and participation enthusiasm, to break the bondage of traditional personnel training mode full , change the education target fuzzy , students' employment is not clear, the one-sided emphasis on the present situation of the theoretical knowledge, problem solving ability is weak, efforts to develop strong social adaptation ability, sufficient to the development of the advanced manufacturing technology was applied undergraduate talents.

\section{ACKNOWLEDGMENT}

This work is supported by Anhui University of Science major teaching and research project (Exploration on the Base Construction for Engineering Practice Training based on CDIO No: 2016xjzdxm-15).

\section{REFERENCES}

[1] Planning division. One of the interpretations of "made in China 2025" : made in China 2025, the grand blueprint of China's manufacturing power construction [EB/OL]. (2015-05-19)

[2] Xiaoqiong Zuo, Jianping Jia. Reform and exploration of applicationoriented undergraduate talent training mode in the context of China manufacturing 2025 [J]. Theoretical exploration, 2015.

[3] Bo Shao. On applied undergraduate talents [J]. Chinese university teaching, 2014.(5):30-33.

[4] Meige Liu. Current situation and problem analysis of applied undergraduate talent training [J]. Science and education, 2014,(11):3435 .

[5] Planning division. Third interpretation of made in China 2025: the situation and environment of China's manufacturing industry. [EB/OL]. (2015-05-19)

[6] Zhijing Yu, Mei Liu. Made in China 2025 and technical skills training [A]. Spotlight. 2015. (21). 